\title{
Evaluation of Apical Extrusion of Debris, Irrigant Solution and Bacteria after Canal Instrumentation using iRace, WaveOne and ProTaper NEXT: An In Vitro Study
}

\author{
Tinsy M Titty ${ }^{1}$, Arathi Rao ${ }^{1}$, Ethel Suman ${ }^{2}$, Ramya Shenoy ${ }^{3}$, Suprabha BS ${ }^{1}$
}

\begin{abstract}
Aim: Extrusion of debris during endodontic preparation carries the risk of flare-ups. Purpose of this study was to evaluate and compare the three different rotary systems (ProTaper Next, WaveOne and iRace) for the amount of debris, irrigant, and bacteria they extruded apically.

Materials and methods: Present study is an in vitro, experimental single-blinded randomized study. Thirty extracted premolars were used for the study. Biomechanical preparations of the specimens were done using either ProTaper Next, WaveOne or iRace file systems. The apically extruded irrigant was collected and measured using the Myers and Montgomery model. Statistical analysis was done using Mann-Whitney and Kruskal-Wallis test. The level of significance was set at $<0.05$.

Results: Study revealed that WaveOne extruded least bacteria and debris and Protaper Next the highest which was statistically significant. WaveOne group and Protaper Next had more number of irrigant extrusion than iRace. The difference between WaveOne and iRace was statistically significant. A significant difference was noted in the amount of debris, bacteria, and irrigant between WaveOne and iRace. A significant difference was also noted in the amount of debris, irrigant, and bacteria extruded between Protaper Next and iRace.

Conclusion: Significant amount of debris and bacterial extrusion was seen in ProTaper Next followed by iRace and WaveOne, whereas apical extrusion of irrigant solution, was greater with WaveOne than ProTaper Next and iRace.

Clinical significance: WaveOne causes the least extrusion of debris and bacteria and this outcome would help in the selection of the system while choosing the rotary system for endodontic treatment.
\end{abstract}

Keywords: Periapical extrusion, ProTaper, iRace, Rotary, WaveOne.

World Journal of Dentistry, (2019): 10.5005/jp-journals-10015-1613

\section{INTRODUCTION}

Elare-ups are a well-known endodontic complication that poses a

- problem for the patient as well as the treating dentist requiring additional visits and active intervention at the minimum. ${ }^{1,2}$

The etiology of flare-ups is complex and involves the host factors, clinical procedure, and microbial factors. ${ }^{3,4}$ Flare-ups can be avoided to a large extent by minimizing the extrusion of canal contents such as necrotic pulp tissue, irrigants, dentinal shavings, bacteria, and their byproducts during the biomechanical preparation. ${ }^{5}$ These extruded materials are cited as some of the major factors involved in mid-treatment flare-ups. ${ }^{6}$

Various studies have proved that all instrumentation techniques tend to invariably extrude debris apically to some extent., ${ }^{7,8}$

Studies in the recent past have suggested that the rotational motion utilized by newer generation rotary techniques are said to be responsible for lesser apical extrusion..$^{9-12}$ The flutes of the file tend to pull dentinal debris into it and direct it coronally away from the canal thereby reducing the apical extrusion of potentially harmful debris, irrigant, and bacteria. ${ }^{9,13}$

One such improved file system is the ProTaper NEXT, a modification of the rotary Protaper Universal file system which is claimed to have better shaping efficacy and increased strength and fracture resistance due to its rectangular cross section. ${ }^{14}$

Another recently evolved generation of NiTi rotary files is iRace which consists of a sequence of only three files thereby reducing the number of files and instrumentation time. The files have a unique design with alternating edges which prevent screwing in of the file and also have a triangular cross section thus increasing the cutting efficacy. ${ }^{15}$ WaveOne a nickel-titanium rotary file of the
Department of Paedodontics and Preventive Dentistry, Manipal College of Dental Sciences, A Constituent Institution of Manipal Academy of Higher Education, Manipal, Mangaluru, Karnataka, India

${ }^{2}$ Department of Microbiology, Kasturba Medical College, A Constituent Institution of Manipal Academy of Higher Education, Manipal, Mangaluru, Karnataka, India

${ }^{3}$ Department of Public Health Dentistry, Manipal College of Dental Sciences, A Constituent Institution of Manipal Academy of Higher Education, Manipal, Mangaluru, Karnataka, India

Corresponding Author: Arathi Rao, Department of Paedodontics and Preventive Dentistry, Manipal College of Dental Sciences, A Constituent Institution of Manipal Academy of Higher Education, Manipal, Mangaluru, Karnataka, India, Phone: +919845242079, e-mail: arathi.rao@manipal.edu

How to cite this article: Titty TM, Rao A, Suman E, Shenoy R, Suprabha BS. Evaluation of Apical Extrusion of Debris, Irrigant Solution and Bacteria after Canal Instrumentation using iRace, WaveOne and ProTaper NEXT: An In Vitro Study. World J Dent 2019;10(2):103-108.

Source of support: Nil

Conflict of interest: None

greater taper which utilizes a unique reciprocating movement, simulating the reverse balanced force technique and allows root canals preparation with one single file in lieu of a sequence of files is another addition to the file systems. ${ }^{16}$

Thus the objective of this study was to evaluate and compare the efficacy of these recent advanced rotary systems based on the amount of debris, irrigant solution and intracanal bacteria they extruded apically. The null hypothesis was that there was no

(O) The Author(s). 2019 Open Access This article is distributed under the terms of the Creative Commons Attribution 4.0 International License (https://creativecommons. org/licenses/by-nc/4.0/), which permits unrestricted use, distribution, and non-commercial reproduction in any medium, provided you give appropriate credit to the original author(s) and the source, provide a link to the Creative Commons license, and indicate if changes were made. The Creative Commons Public Domain Dedication waiver (http://creativecommons.org/publicdomain/zero/1.0/) applies to the data made available in this article, unless otherwise stated. 
difference in the apical extrusion of debris, bacteria, and irrigant between Protaper Next, WaveOne and iRace rotary file systems.

\section{Materials and methods}

The present study was conducted at the Department of Pedodontics and Preventive Dentistry in association with the Department of Microbiology and Department of Chemical Engineering, over a period of 12 months from October 2016 to October 2017.

This was an in vitro single-blinded study with lottery method of randomization initiated after obtaining ethical clearance from the Institutional ethics committee.

The sample size was calculated using the meads equation, ${ }^{17}$ $E=N-B-T$ where $E$ is the degree of freedom of error component, $\mathrm{N}$ is the total number of individuals or units in the study $\left(\mathrm{N}^{-1}\right), \mathrm{B}$ is the blocking component $\left(\mathrm{B}^{-1}\right)$ and $T$ is the treatment component $\left(\mathrm{T}^{-1}\right) .10 \%$ of back up for drop out was added and the sample was calculated to be 10 per group and a total of 30 .

\section{Selection and Preparation of Sample}

Thirty mandibular single-rooted premolars with closed apices extracted for orthodontic treatment were selected for the study considering the inclusion and exclusion criteria.

\section{Inclusion Criteria}

Noncarious intact premolars with single apical foramen.

\section{Exclusion Criteria}

Premolars with immature root, a tooth with fractured root, multiple canals, calcified canals, root caries or any other gross developmental abnormalities

The teeth were examined using operating loupes (Magni Vision, Confident, India). The selected teeth were cleaned of any soft tissue remnants or surface debris and stored in saline

Endodontic access cavities were prepared in them using Endo Access Bur (MANI DIA burs, Japan) in a high-speed handpiece (PANA-AIR, Nakanishi Inc., Kanuma, Japan). A 10 K file (Dentsply Maillefer, Ballaigues, Switzerland) was used to assess the patency and working length. The pulpal tissue was extirpated with a barbed broach. The access cavity later served as a reservoir for the Enterococcus faecalis (ATCC 29212) suspension.

The external root surfaces of all the premolars were coated with three coats of nail varnish to prevent microleakage from external canals. A $10 \mathrm{~K}$ file was used to create a standardized foramen by piercing it through the apex such that the size of apical foramen was consistent and apical patency was maintained.

- Test apparatus: A model system proposed by Myers and Montgomery et al. ${ }^{18}$ in 1991 was used in the study for collecting the extruded bacteria, debris, and irrigant (Fig. 1).

It consisted of an amber colored glass vial with a rubber stopper and a collecting vial suspended in the glass vial. A hole was created in the rubber stopper of the vial for the insertion of the tooth. The tooth was then inserted up to cementoenamel junction (CEJ) level under pressure. The collecting vial was then placed within the glass vial with the root suspended in the collecting vial to collect the material extruded through the apical foramen. A 24 gauge needle was used to vent the stopper on the vial to equalize the air pressure. The whole apparatus was then autoclaved at $121^{\circ} \mathrm{C}$ for 15 minutes at $15 \mathrm{lbs}$.

The collecting vials were preweighed using an electronic balance of $10^{-5}$ precision(MYA 5.3Y microbalance, RADWAG balances, and scales, USA). For measuring the weight three readings were taken and their mean recorded.

\section{Contamination of the Root Canals}

One $\mathrm{mL}$ of $E$. faecalis (ATCC 29212) culture, grown in brain heart Infusion broth (over 24 hours) was used to contaminate the root canals. Turbidity was adjusted to $0.5 \mathrm{McF}$ arland standards such that the bacterial count was $1.5 \times 10^{8} \mathrm{CFU} / \mathrm{mL} .{ }^{9}$ All the access cavities were filled with the bacterial suspension using a pipette while a 10 $K$ file was used to carry the bacteria down the entire canal length, which was kept in an incubator at $37^{\circ} \mathrm{C}$ for 24 hours. Once this was done the teeth were randomly allocated to the three test groups using simple random sampling:

- Group 1: Protaper Next (Dentsply Ltd) rotary group

- Group 2:WaveOne(Dentsply Maillefer)rotary group

- Group 3: iRace rotary (FKG Dentaire SA) group

\section{Root Canal Preparation}

A single operator performed the root canal preparation, under a class I laminar airflow biosafety cabinet (Rotek, India) to maintain an aseptic environment and prevent bacterial contamination. The teeth belonging to groups I, II and III were instrumented with Protaper NEXT, WaveOne, iRacefiles respectively as per the manufacturer's recommendation. Between each file, irrigation was done with $3 \mathrm{~mL}$ distilled water using a 22 gauge needle passively kept $3 \mathrm{~mm}$ short of the working length.

\section{Sequence of Instrumentation}

- Group 1 (ProTaper NEXT):Ten specimens were instrumented with ProTaper NEXT files in a crown down manner using gentle in and out motions using $X_{1}$ and $X_{2}$ files with a torque controlled endodontic motor (X-Smart Plus, Dentsply Maillefer) at $300 \mathrm{rpm}$ and a torque of $2.6 \mathrm{Ncm}$. The root canal was flared using SX file from the universal Protaper (Dentsply Tulsa Dental, Tulsa, OK). This as followed by the $X_{1}$ and $X_{2}$ file. On meeting obstruction the file was removed, the canal irrigated, recapitulated, and the file reintroduced into the canal again. The instrumentation was continued till the $\mathrm{X}_{1}$ and $\mathrm{X}_{2}$ file both reached working length.

- Group2(WaveOne):Ten specimens were instrumented by single reciprocating file WaveOne primary file (Dentsply Maillefer) using a pecking motion. The root canal was flared using SX file from the universal Protaper (Dentsply Tulsa Dental, Tulsa, OK). A preprogrammed reciprocating Endomotor (X-Smart Plus,
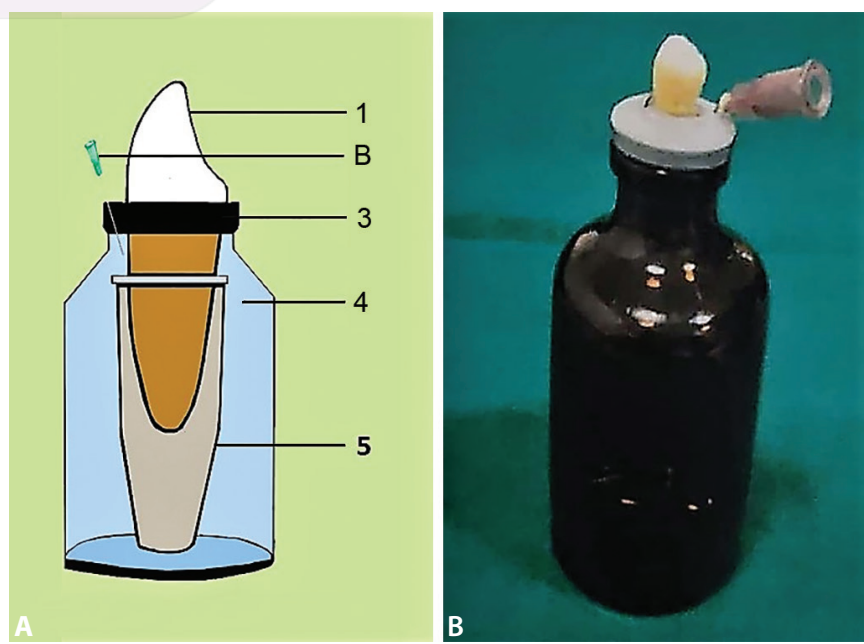

Figs 1A and B: (A) Diagram of the test apparatus (1-tooth, 2-22 gauge needle, 3-rubber cap, 4-glass vial, 5-collecting vial; (B) photograph of the test apparatus 
Dentsply Maillefer) possessing the program for WaveOne files instrumentation was used. The flutes of the file were cleaned after every three pecks. On meeting obstruction, the file was removed, the canal irrigated, recapitulated, and the file reintroduced into the canal again. The instrumentation was done until the WaveOne primary file reached the apex.

- Group 3 (iRace): Ten specimens were instrumented using iRace rotary files. The root canal was flared using SX file from the universal Protaper (Dentsply Tulsa Dental, Tulsa, OK). For iRace group, an endodontic motor (X-Smart, Dentsply Maillefer) was set at $600 \mathrm{rpm}$ and a torque of $1.5 \mathrm{Ncm}$. R1 file (15/0.06) followed by R2 file (25/0.04) was used in a sequential manner up to the working length. A $15 \mathrm{~K}$-file was used for recapitulating between each file to prevent the apical blockage.

\section{Measurement of the Extruded Irrigant}

Following canal preparation, the solution that was collected in the collecting vials was thoroughly mixed in a Vortex mixer (CM 101 Cyclomixer, Remi, India) for 5 minutes and debris allowed to sediment for 10 minutes. Micropipettes were used to measure the volume of extruded irrigant.

\section{Measurement of the Bacteria}

About $0.01 \mathrm{~mL}$ of the extruded irrigant was pipetted out of the collecting vial and using a sterile cotton swab the suspension was plated on Mueller Hinton agar plates at $37^{\circ} \mathrm{C}$ and incubated for 24 hours (Fig. 2). The counting of bacteria was done using surface plating method..$^{19}$ In this method, the viable count of the bacteria was calculated by taking the average colony count per plate.

\section{Measurement of the Debris}

The root apex was washed using $1 \mathrm{~mL}$ distilled water into the collecting vial to procure any debris sticking to the external root surface. The collecting vials were then incubated at $37^{\circ} \mathrm{C}$ till the irrigant evaporated. The collecting vials were weighed using a $10^{-5}$ precision electronic balance (MYA 5.3Y microbalance, RADWAG balances, and scales, USA). Three subsequent readings were taken for every sample recording the mean. The amount of apically extruded debris was obtained by subtracting the postoperative weight of the collecting vial from the preoperative weight of the collecting vial.

Data analysis was carried out using statistical package for the social sciences (SPSS) version 16 software. $p<0.05$ was considered significant. Extrusion of irrigant, debris and bacteria were assessed using the independent Kruskal-Wallis test. Intergroup comparison was done using Mann-Whitney tests to test for significant differences.

\section{Results}

The mean value of debris, bacteria, and irrigant extruded (in mg) obtained in each group are shown in Table 1. The maximum debris extrusion was seen in Protaper NEXT group $(1.21 \mathrm{mg})$ followed by iRace group $(0.21 \mathrm{mg})$ and the least in WaveOne group (0.05 $\mathrm{mg}$ ). Maximum irrigant extrusion was in WaveOne $(0.62 \mathrm{mg})$ and Protaper Next groups $(0.62 \mathrm{mg})$ and least was by iRace rotary system $(0.20 \mathrm{mg})$. The maximum bacteria extruded was in the Protaper Next group (246.40 CFU/mL) followed by iRace group (158.80CFU/mL), while WaveOne group had the least amount of bacteria extrusion (14.60 CFU/mL).
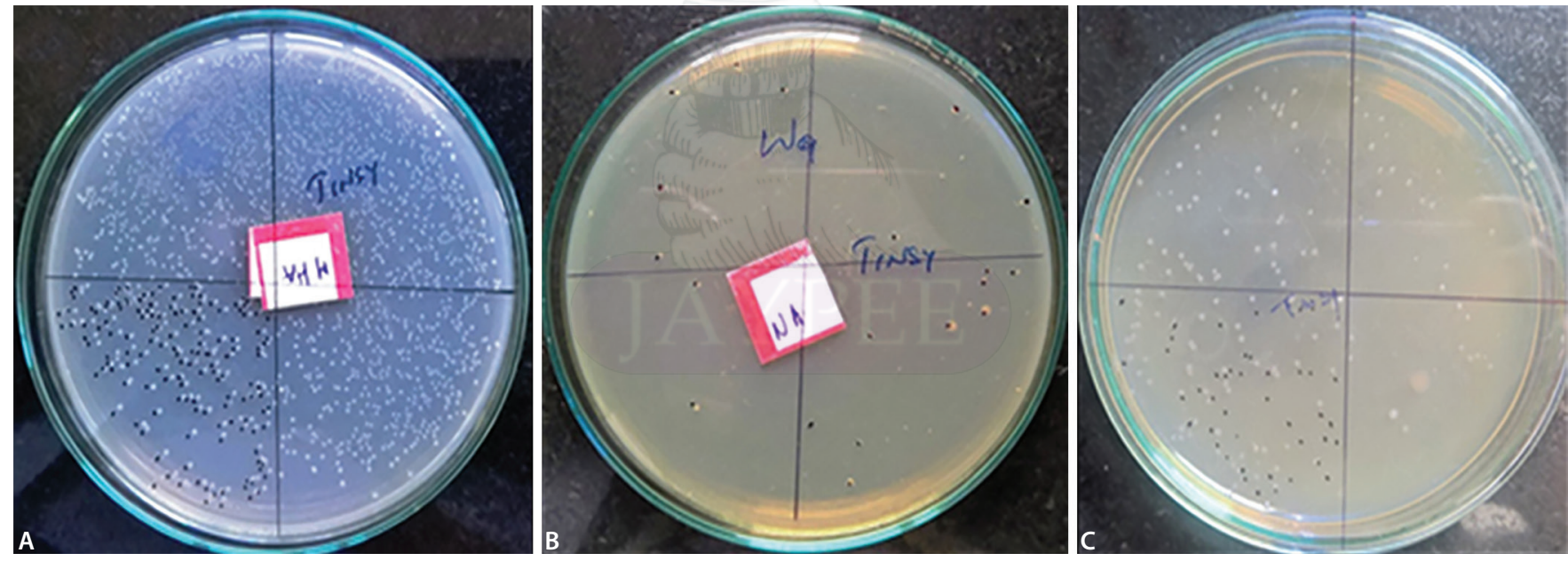

Figs 2A to C: E. faecalis growth on Mueller Hinton agar plates. (A) ProTaper NEXT rotary system; (B) WaveOne rotary system; (C) iRace rotary system

Table 1: Descriptive statistics and association between extrusion of irrigant, debris, and bacteria (using independent Kruskal-Wallis test)

\begin{tabular}{llll}
\hline & Debris $($ in $\mathrm{mg})$ & Volume of irrigant (in $\mathrm{mL})$ & Bacteria $($ CFU $/ \mathrm{mL})$ \\
\hline ProTaper Next & $1.21 \pm 2.21$ & $0.62 \pm 0.06$ & $246.40 \pm 41.41$ \\
WaveOne & $0.05 \pm 0.03$ & $0.62 \pm 0.15$ & $14.60 \pm 2.76$ \\
iRace & $0.21 \pm 0.09$ & $0.20 \pm 0.05$ & $158.80 \pm 22.47$ \\
Test statistic & 25.351 & 19.561 & 25.864 \\
Degree of freedom & 2 & 2 & 2 \\
${ }^{*} p$ value & $<0.001$ & $<0.001$ & $<0.001$ \\
\hline
\end{tabular}

${ }^{*} p<0.05$ is significant 
Evaluation of Apical Extrusion

Table 2: Comparison of apical extrusion of irrigant, bacterial, debris using Mann Whitney analysis between group I (ProTaper NEXT) and group II (WaveOne) and group III (iRace)

\begin{tabular}{lllllll}
\hline & & $\begin{array}{l}\text { Mann-Whitney } \\
\text { statistics }\end{array}$ & Wilcoxon $W$ & Test statistic & Standard error & $p$ value \\
\hline Group I and II & Debris $(\mathrm{mg})$ & 0.000 & 55 & 3.790 & 13.194 & 0.000 \\
& Irrigant $(\mathrm{mL})$ & 44 & 99 & 0.457 & 13.13 & 0.684 \\
& Bacteria $(\mathrm{CFU} / \mathrm{mL})$ & 0.000 & 55 & 3.791 & 13.19 & 0.000 \\
\hline Group II and III & Debris $(\mathrm{mg})$ & 100 & 155 & 3.791 & 13.19 & 0.000 \\
& Irrigant $(\mathrm{mL})$ & 0.000 & 55 & 3.791 & 13.19 & 0.000 \\
& Bacteria $(\mathrm{CFU} / \mathrm{mL})$ & 100 & 155 & 3.787 & 13.20 & 0.000 \\
\hline Group I and III & Debris $(\mathrm{mg})$ & 2 & 57 & 2 & 3.790 & 0.000 \\
& Irrigant $(\mathrm{ml})$ & 0.000 & 55 & 0.000 & 3.805 & 0.000 \\
& Bacteria $(\mathrm{CFU} / \mathrm{mL})$ & 0.000 & 55 & 0.000 & 3.633 & 0.000 \\
\hline
\end{tabular}

${ }^{*} p<0.05$ is significant

Intergroup comparison using Kruskal-Wallis test revealed that the amount of debris, volume of irrigant and bacteria was statistically significant in all the three groups (Table 1). The $p$ value was kept as $\leq 0.05$. Mann-Whitney analysis (Table 2) revealed there was a significant difference in the extruded debris and bacteria between Protaper NEXT and WaveOne groups $(p=0.000)$. However, no significant difference was noted in the amount of irrigant extruded ( $p=0.684$ ) between ProTaper NEXT and WaveOne. There was a significant difference $(p=0.000)$ in the amount of debris, bacteria, and irrigant between WaveOne and iRace. A significant difference $(p=0.000)$ was also noted in the amount of debris, irrigant, and bacteria extruded between Protaper NEXT and iRace group.

\section{Discussion}

Mandibular premolars having a single root and the single canal was clinically evaluated and selected using operating loupes. This was done as factors like the presence of more than one canal, and the canal curvature have been known to affect the amount of apical extrusion. ${ }^{20-22}$

Several methods have been cited in the literature to quantify the extrusion of debris and irrigant; however, the method given by Myers and Montgomery ${ }^{18}$ in 1991 has been most widely used. ${ }^{9,23}$ This method simulates real clinical conditions as it does not allow the operator to visually perceive the apical foramen whilst canal preparation, by making use of amber colored glass vial in which the tooth is suspended, thereby reducing operator bias. However, it has some inherent disadvantages like being unable to replicate periapical resistance. The canals were preflared using an Sx file as coronal flaring has been reported to improve the control over instrument while preparing the apical third of the canal. ${ }^{24}$

The apical patency of the premolars was maintained by using a $10 \mathrm{~K}$-file to achieve standardization of apical diameters. Tinaz et al. ${ }^{25}$ have shown that as the apical diameter increases, the debris extrusion also increases, while Lambrianidis et al. ${ }^{26}$ has paradoxically reported that greater amount of extrusion with intact apical constriction. Apical preparation was standardized in all the groups by keeping the master apical file size the same $(25 \mathrm{~mm})$.

In order to further decrease variability the amount of irrigant was kept constant $(3 \mathrm{~mL})$ for all specimens, the depth of irrigation needle insertion was determined at an established level ( $3 \mathrm{~mm}$ from working length); and the irrigant passively injected to minimize any undue forces on the irrigating syringe. ${ }^{27}$

Enterococcus faecalis was used as a bacteriological marker in the present study as they have been found in the oral cavity. ${ }^{28}$ They have been implicated in persistent root canal infections owing to their facultative anaerobic nature and have been retrieved from root canals of teeth with post-treatment disease. ${ }^{29}$

Over the years, a variety of $\mathrm{NiTi}$ instruments have emerged all aimed at overcoming the limitations encountered in earlier systems. The differences obtained in various studies may be attributed to variation in following characteristics of the instruments: (i) the preparation technique (ii) the varied cross-sectional design of the file and (iii) the apical tapers of the instruments. ${ }^{14}$

The descriptive results of the present study revealed extrusion of debris, bacteria, and irrigant in all the groups regardless of the file design or kinematic motion involved confirm the findings of previous studies. Many earlier studies have affirmed that all instrumentation techniques produce apical extrusions ${ }^{7,14}$ reinforcing the fact that it is impossible to clean and shape canal chemo mechanically without causing apical extrusions. Subsequent studies in endodontic literature ${ }^{9,21,25}$ have also shown that all engine-driven instruments extruded lesser intracanal bacteria than manual instruments. Reddy and Hicks suggested that the rotational motion produced by enginedriven instruments tended to pack dentinal debris into the flutes of the file and direct them towards the orifice away from the apical foramen thereby reducing their extrusion. ${ }^{21}$

The results from the existing studies are controversial in regard to the type of engine-driven system causing lesser apical extrusions. While some indicated that continuous rotational movement extruded a lesser amount of debris ${ }^{30-32}$ others demonstrated a higher amount of debris extrusion with continuous rotation compared to reciprocation motion. 16,33,34

Hence the null hypothesis regarding WaveOne files extrude lesser debris and bacteria was accepted.

The reason for such a finding can be attributed to the following reasons:

WaveOne files are designed to work in an unequal reciprocating motion which is similar to a mechanized balanced force pressure less technique while the balanced force technique apparently allows better control over the apically extruded debris as suggested by Yared in $2008 .^{35}$

The reciprocating motion squeezes the debris and bacteria into the flutes and carries it out of the canal reducing debris extrusion. 
The tip of the WaveOne also features a debris diversion trench on each cutting edge, which further reduces the tendency for apical extrusion into the periradicular tissues. ${ }^{16}$

The descriptive statistics also revealed that WaveOne produced greater extrusion of irrigant. However, the intergroup comparison using Mann-Whitney test revealed that the difference was not significant between WaveOne and ProTaper Next but was significant when compared to iRace. This was in agreement with the findings obtained by Singh et al. ${ }^{36}$ in their study on comparison of apical extrusion of irrigant and debris using hand files, rotary files, and reciprocating file systems. They found greater extrusion of irrigant with WaveOne reciprocating files compared to Mtwo rotary files which were however statistically insignificant. They attributed the finding to the fact that the WaveOne file is quite big and rigid with an increased taper (0.08) directed to reach the apex. This might also explain the increased extrusion of irrigant seen with WaveOne files compared to ProTaper NEXT $\left(X_{2}\right.$ 0.06) and iRace files $\left(R_{2}\right.$ 0.04) with iRace extruding significantly lesser irrigant compared to WaveOne. Hence the null hypothesis that reciprocating files lead to lesser irrigant extrusion was rejected.

The reason iRace files system produced lesser debris and bacterial extrusion compared to ProTaper NEXT and WaveOne may be presumably due to its triangular cross-sectional design and small core diameter, which provides more space to carry debris towards the root canal orifices. Moreover, other features of iRace, such as its alternate cutting edges, prevent screwing in and hence extrusions as per the manufacturers. ${ }^{15}$

\section{Conclusion}

Under the conditions of this in vitro study, all the three systems significantly extruded debris, irrigants and bacterial apically. It may be concluded that the amount of debris and bacterial extrusion was significantly greater in Protaper Next than iRace and WaveOne, whereas apical extrusion of irrigant solution, was greater with WaveOne than Protaper Next and iRace but the difference between the three was not significant.

\section{LIMITATIONS OF THE STUDY}

The present study is an in vitro study which may not exactly replicate the intraoral condition.

\section{References}

1. Imura N, Zuolo ML. Factors associated with endodontic flare-ups: a prospective study. Int Endod J 1995;28(5):261-265.

2. Walton R, Fouad A. Endodontic interappointment flare-ups: a prospective study of incidence and related factors. J Endod 1992;18(4):172-177.

3. Seltzer S, Naidorf IJ. Flare-ups in endodontics: I. Etiological factors. J Endod 1985;11(11):472-478.

4. Torabinejad M, Kettering JD, McGraw JC, et al. Factors associated with endodontic interappointment emergencies of teeth with necrotic pulps. J Endod 1988;14(5):261-266.

5. Gambarini G, Testarelli L, De Luca M, et al. The influence of three different instrumentation techniques on the incidence of postoperative pain after endodontic treatment. Ann Stomatol (Roma) 2013;4(1):152-155.

6. Logani A, Shah N. Apically extruded debris with three contemporary $\mathrm{Ni}$-Ti instrumentation systems: An ex vivo comparative study. J Dent Res.2008; 19(3):182-185.

7. De-Deus G, Brandao MC, Barino B, et al. Assessment of apically extruded debris produced by the single file ProTaper F2 technique under reciprocating movement. Oral Surg Oral Med Oral Pathol Oral Radiol Endod 2010;110(3):390-394.
8. Martin H, Cunningham WT. The effect of endosonic and hand manipulation on the amount of root canal material extruded. Oral Surg Oral Med Oral Pathol 1982;53(6):611-613.

9. Kalra P, Rao A, Suman E, et al. Evaluation of conventional, Protaper hand and Protaper rotary instrumentation system for apical extrusion of debris, irrigants and bacteria-An in vitro randomized trial. J Clin Exp Dent 2017;9(2):e254-e258.

10. Garlapati R, Venigalla BS, Patil JD, et al. Quantitative evaluation of apical extrusion of intracanal bacteria using K3, Mtwo, RaCe and protaper rotary systems: An in vitro study. J Conserv Dent 2013; 16(4):300-303.

11. Ghivari SB, Kubasad GC, Deshpande P. Comparitive evaluation Of apical extrusion of bacteria using hand and rotary systems: An in vitro study. J Conserv Dent 2012;15(1):32-35.

12. Reddy SA, Hicks ML. Apical extrusion of debris using two hand and two rotary instrumentation techniques. J Endod 1998;24(3): 180-183.

13. Hegde MN, Thatte S. Comparison of the amount of apical extrusion of bacteria following the use of different instrumentation techniques-An in vitro study. Nitte Univ J Health Sci 2011;1:27-32.

14. Topçuoğlu G, Topçuoğlu HS, Akpek F. Evaluation of apically extruded debris during root canal preparation in primary molar teeth using three different rotary systems and hand files. Int J Paediatr Dent 2016; 26(5):357-363.

15. iRace Brochure. Available from https://www.fkg.ch/sites/default/ files/201705_fkg_irace_brochure_en.pdfAccessed on 24th January 2019.

16. Lu Y, Chen M, Qiao F, Wu L. Comparison of apical and coronal extrusions using reciprocating and rotary instrumentation systems. BMC Oral Health 2015;15:1-7.

17. Festing MF, Altman DG. Guidelines for the design and statistical analysis of experiments using laboratory animals. ILAR J 2002;43:244258.

18. Myers GL, Montgomery S. A comparison of weights of debris extruded apically by conventional filing and canal master techniques. Endod 1991; 17(6): 275-279.

19. Sanders, E.R. Aseptic Laboratory Techniques: Plating Methods. J Vis Exp 2012;63:1-18.

20. Tanalp J, Kaptan F, Sert S, et al. Quantitative evaluation of the amount of apically extruded debris using 3 different rotary instrumentation systems. Oral Surg Oral Med Oral Pathol Oral Radiol Endod 2006; 101(2):250-257.

21. Reddy SA, Hicks ML. Apical extrusion of debris using two hand and two rotary instrumentation techniques. J Endod 1998;24(3):180-183.

22. Ferraz CC, Gomes NV, Gomes BP, et al. Apical extrusion of debris and irrigants using two hand and three engine-driven instrumentation techniques. Int Endod J 2001;34(5):354-358.

23. Caviedes-Bucheli J, Castellanos F, Vasquez N, et al. The influence of two reciprocating single-file and two rotary-file systems on the apical extrusion of debris and its biological relationship with symptomatic apical periodontitis. A systematic review and meta-analysis. IntEndod J 2016; 49(3):255-270.

24. Kuştarci A, Akpinar KE, Er K. Apical extrusion of intracanal debris and irrigant following use of various instrumentation techniques. Oral Surg Oral Med Oral Pathol Oral Radiol Endod 2008;105(2): 257-262.

25. Tinaz AC, Alacam T, Uzun O, et al. The effect of disruption of apical constriction on periapical extrusion. J Endod 2005;31(7):533-535.

26. Lambrianidis T, Tosounidou E, Tzoanopoulou M. The effect of maintaining apical patency on periapical extrusion. J Endod 2001; 27(11):696-698.

27. Azar NG, Ebrahimi G. Apically-extruded debris using the Protaper system. Aust Endod J 2005; 31(1):21-23

28. Er K, Sümer Z, Akpinar KE. Apical extrusion of intracanal bacteria following use of two engine-driven instrumentation techniques. Int Endod J. 2005; 38(12):871-876.

29. Kuştarci A, Akpinar KE, Er K. Apical extrusion of intracanal debris and irrigant following use of various instrumentation techniques. Oral Surg Oral Med Oral Pathol Oral Radiol Endod 2008;105(2): 257-262. 
30. Surakanti JR, Venkata RC, Vemisetty HK, et al. Comparative evaluation of apically extruded debris during root canal preparation using Protaper $^{\mathrm{TM}}, \mathrm{Hyflex}^{\mathrm{TM}}$ and Waveone ${ }^{\mathrm{TM}}$ rotary systems. J Conserv Dent 2014;17(2):129-132.

31. Nayak G, Singh I, Shetty S, et al. Evaluation of apical extrusion of debris and irrigant using two new reciprocating and one continuous rotation single file systems. J Dent (Tehran) 2014;11(3):302-309.

32. Bürklein S, Schäfer E. Apically extruded debris with reciprocating single-file and full-sequence rotary instrumentation systems. J Endod 2012;38(6):850-852.
33. Üstün $Y$, Çanakçi BC, Dinçer AN, et al. Evaluation of apically extruded debris associated with several Ni-Ti systems. Int Endod J 2015; 48(7):701-704.

34. Tinoco JM, De-Deus G, Tinoco EM, Saavedra F, Fidel RA, Sassone LM. Apical extrusion of bacteria when using reciprocating single-file and rotary multifile instrumentation systems. Int Endod J 2014;47(6):560-566.

35. Yared G. Canal preparation using only one Ni-Ti rotary instrument: preliminary observations. Int Endod J 2008;41(4):339-344.

36. Singh A, Arunagiri D, Pushpa S, et al. Apical extrusion of debris and irrigants using Protaper hand, $\mathrm{M}$-two rotary and WaveOne single file reciprocating system: An ex vivo study. J Conserv Dent 2015; 18(5):405-408. 